\title{
Incidence and evaluation of open bite malocclusion and their management
}

Rahman MA ${ }^{1}$ BDS, FCPS and Hossain MZ² BDS, PhD

\begin{abstract}
Introduction: Open bite malocclusion is one of the most difficult dentofacial deformities to treat. Although this type of malocclusion can occur unilaterally or bilaterally in the buccal segments. It is mostly seen in the anterior segment where there is no incisal contact and vertical overlap of the lower incisors by the uppers.
\end{abstract}

Objectives: The study was aimed to find out the incidence of open bite malocclusion and their pre and post treatment evaluation of the treated cases and also compare the result of two study groups (skeletal open bite and dental open bite).

Methods: A total number of 31 patients with open bite malocclusion out of 1372 patients reported to Department of Orthodontics, Dhaka Dental College and Hospital for treatment. Out of them 21 patients were included in this study with mean age $22 \pm 5.4$, who successfully completed treatment. Of them 14 were included in the dental group and 07 in the skeletal group. Pre treatment history, clinical examination along with pre and post-treatment photographs, study models and lateral cephalograms were used to compare the treatment outcome between the two study groups.

Results: The incidence of open bite was $2.3 \%$. Out of 21 open bite samples 14 were of dental type and the rest 07 were of skeletal type. $47.6 \%$ open bite had Angles Class I malocclusion, $42.9 \%$ were Class II and $9.5 \%$ were Class III. Cephalometric analysis of vertical measurements showed that the mandibular plane angle, palatal plane angle and SNA angle significantly decreased from pre-treatment to post-treatment $(\mathrm{p}<0.05)$ in both groups . Gonial angle remains unchanged. Cephalometric analysis of the linear and dental measurements showed increased upper face height, posterior facial height and inter-incisal angle. Soft tissue evaluation on cephalometry showed significant decrease of esthetic plane and interlabial gap. A statistically significant mean difference was found in case of negative overbites among the patients with dental group $(\mathrm{p}<0.001)$. Less time was required for completion of treatment in dental group and prognosis was significantly better $(\mathrm{p}<0.05)$

Conclusion: The result of the present study indicates that the treatment period and wear time of appliance in dental type was shorter than skeletal type. Both groups showed significant improvement though prognosis was better in dental type of open bite cases.

Key words: Open Bite malocclusion, Skeletal, Dental. (Bangladesh Journal of Orthodontics and Dentofacial Orthopedics, Vol. 2, No. 2, April 2012, p 1-7).

\section{INTRODUCTION}

The open bite malocclusion is one of the most difficult dentofacial deformities to treat. The complexity of this malocclusion is attributed to a combination of skeletal, dentoalveolar, functional, and habit related factors. Accurate diagnosis is essential for proper treatment planning, which, in combination with patient-specific mechanics, is needed to achieve stable result. ${ }^{1-14}$

The incidence of anterior open bite varies among races and with dental age. It is more common in Americans (6.6\%) than in Caucasians $(2.9 \%)$ or Hispanics $(2.1 \%) .{ }^{15}$ Other studies in different countries show $8 \%$ in Kenya, ${ }^{16} 6.6 \%$ in Saudi Arabian adolescents, ${ }^{17}$ 9\% in Bogota, Columbia, ${ }^{18} 4 \%$ in Pakistan. ${ }^{19}$ In Bangladesh a study report states $1 \%$ incidence of open bite malocclusion in $1994^{20}$ and another study reports $4.5 \%$ in $2007 .{ }^{21}$ Chronological, as children develop dentally, the incidence of anterior open bite decreases, as it tends to self correct during the mixed dentition phase.

Although the term open bite typically refers to a dental malocclusion, it can be the result of a dental discrepancy, skeletal discrepancy, or a combination of the two. Terms such as skeletal open bite, vertical growth, hyperdivergent and long-face pattern have been used to describe open bites that may be caused, at least partially, by a skeletal problem. Most of the skeletal and dental characteristics commonly seen in open bite patients were initially described by Bjork. ${ }^{22}$ These skeletal and dental characteristics include: distal condylar inclination, short ramus, antegonial notching, obtuse gonial angle, excessive maxillary height, straight mandibular canal, thin and long symphysis, long anterior facial height, short posterior facial height, steep mandibular plane, divergent occlusal planes, acute intermolar and interincisal angulation, anteriorly tipped up palatal plane, and extruded

${ }^{1}$ Lieutenant Colinel, Combined Military Hospital, Rangpur Cantonment. ${ }^{2}$ Professor and Head, Dept of Orthodontics, Dhaka Dental 
molars. Of all these characteristics, the steepness of the mandibular plane has been considered the skeletal finding associated with a skeletal anterior open bite. ${ }^{23-27}$

In terms of soft tissue characteristics, most parallel those of hard tissues (long lower facial height, steep mandibular plane, and short posterior facial height). In addition a large interlabial gap is most evident on clinical examination of a skeletal open bite patient. 28,29

Open bites associated with craniofacial malformations are much more difficult to treat and tend to relapse. ${ }^{30-34}$ Early treatment of vertical dysplasia during the primary or the mixed dentition period has been advocated to reduce the need of treatment in the permanent dentition. A series of treatment approaches to be made regarding treatment of open bite. These treatment modalities include mainly functional appliances, multi bracket techniques, headgears, bite blocks, magnets, implants and orthognathic surgeries etc. ${ }^{35-45}$

\section{MATERIALS AND METHODS}

The study was conducted in the Department of Orthodontics and Dentofacial Orthopaedics, Dhaka Dental College and Hospital, Dhaka from July 2006 to December 2009. The diagnosis of anterior open bite of skeletal or dental origin was made based on clinical findings, model analysis and cephalometric evaluation. A number of 21 patients were selected with no age and sex limit. Of them 7 were classified in skeletal group and 14 were in dental group. Accordingly, treatment plan was made and executed. After starting the treatment, the subjects were advised to report every 28 days for follow-up and activation. All were motivated to maintain optimum oral hygiene.

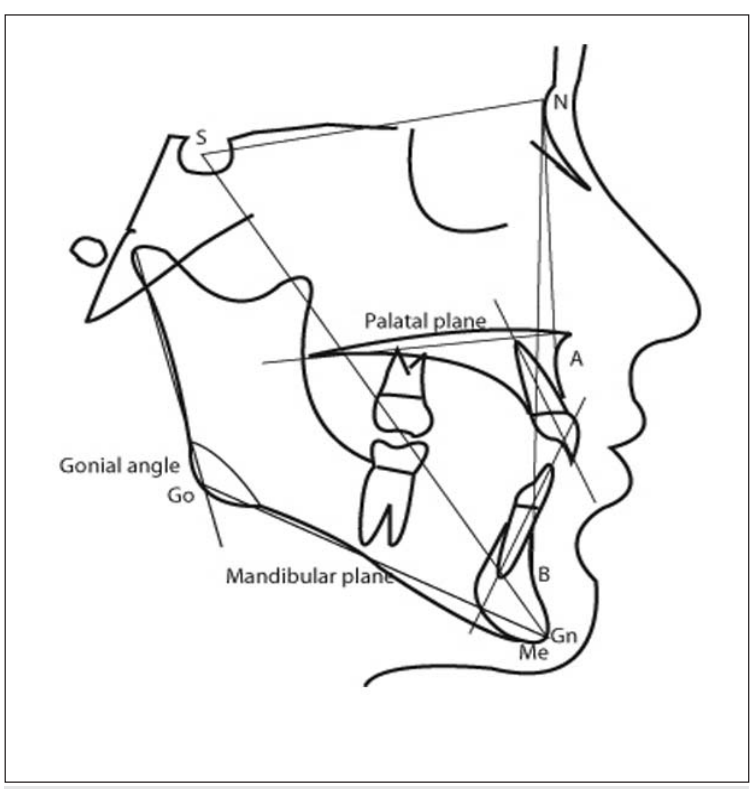

Fig.1: Measurements used in lateral cephalogram
Data were collected from pre and post treatment photographs, study models and lateral cephalograms and a case history sheet for each patient was filled. The collected data was subjected to statistical analysis using the Statistical Package for Social Sciences (SPSS for windows, version 17).

\section{RESULTS}

The prospective study was conducted in the Department of Orthodontics and Dentofacial Orthopedics, Dhaka Dental College and Hospital with a view to assess the incidence of open bite malocclusion among the patients attending for treatment and their post treatment outcome between two groups of patients viz. skeletal and dental. A total of 21 patients were studied, 7 were in skeletal group and 14 patients in Dental group.

Table 1. Year wise distribution of orthodontic patients with openbite

\begin{tabular}{lccc}
\hline Year & $\begin{array}{c}\text { No. of ortho- } \\
\text { dontic } \\
\text { patients }\end{array}$ & $\begin{array}{c}\text { No. open- } \\
\text { bite cases }\end{array}$ & $\%$ \\
\hline $\begin{array}{l}\text { July 2006- } \\
\text { December 2006 }\end{array}$ & 180 & 3 & 1.7 \\
$\begin{array}{l}\text { January 2007- } \\
\text { December 2007 }\end{array}$ & 385 & 9 & 2.3 \\
$\begin{array}{l}\text { January 2008- } \\
\text { December 2008 }\end{array}$ & 397 & 10 & 2.5 \\
$\begin{array}{l}\text { January 2009- } \\
\text { December 2009 }\end{array}$ & 410 & 9 & 2.2 \\
Total & 1372 & 31 & 2.3 \\
\hline
\end{tabular}

Among the attended cases, $2.3 \%$ had open bite. The year wise distribution indicated that the percentage of open bite was more or less consistent from 2007 to 2009 , but in 2006, the percentage of open bite was lower than the subsequent year. 
Table 2. Age distribution of the patients

\begin{tabular}{|c|c|c|c|c|c|c|c|}
\hline \multirow[t]{3}{*}{ Age in years } & \multicolumn{4}{|c|}{ Patient's group } & \multirow{2}{*}{\multicolumn{2}{|c|}{$\begin{array}{l}\text { Total } \\
n=21\end{array}$}} & \multirow[t]{3}{*}{$\mathrm{p}$ value } \\
\hline & \multicolumn{2}{|c|}{$\begin{array}{c}\text { Dental } \\
n=14\end{array}$} & \multicolumn{2}{|c|}{$\begin{array}{c}\text { Skeletal } \\
n=7\end{array}$} & & & \\
\hline & No. & $\%$ & No. & $\%$ & No. & $\%$ & \\
\hline$<20$ & 6 & 42.9 & 1 & 14.3 & 7 & 33.3 & \\
\hline$\geq 20$ & 8 & 57.1 & 6 & 85.7 & 14 & 66.7 & \\
\hline Mean $\pm \mathrm{SD}$ & \multicolumn{2}{|c|}{$22.1 \pm 6.2$} & \multicolumn{2}{|c|}{$21.7 \pm 3.6$} & \multicolumn{2}{|c|}{$22.0 \pm 5.4$} & 0.913 \\
\hline Range & \multicolumn{2}{|c|}{$14.0-36.0$} & \multicolumn{2}{|c|}{$16.0-36.0$} & \multicolumn{2}{|c|}{$14.0-36.0$} & \\
\hline
\end{tabular}

*value reached from Mann-Whitney U test

The mean age of the patients were $22.0 \pm 5.4$ years ranging from 14 to 36 years. The mean age of the skeletal group was $21.7 \pm 3.6$ years and that dental group was $22.1 \pm 6.2$ years. No statistically significant mean difference was found between two groups of patients $\mathrm{p}>0.05$.

Table 3. Sex distribution of the patients

\begin{tabular}{|c|c|c|c|c|c|c|c|}
\hline \multirow[t]{3}{*}{ Sex } & \multicolumn{4}{|c|}{ Patient's group } & \multicolumn{2}{|c|}{$\begin{array}{l}\text { Total } \\
n=21\end{array}$} & \multirow[t]{3}{*}{$\mathrm{p}$ value } \\
\hline & \multicolumn{2}{|c|}{$\begin{array}{c}\text { Dental } \\
\mathrm{n}=14\end{array}$} & \multicolumn{2}{|c|}{$\begin{array}{c}\text { Skeletal } \\
n=7\end{array}$} & \multirow[b]{2}{*}{ No. } & \multirow[b]{2}{*}{$\%$} & \\
\hline & No. & $\%$ & No. & $\%$ & & & \\
\hline Male & 2 & 14.3 & 3 & 42.9 & 5 & 23.8 & $0.280 \S$ \\
\hline Female & 12 & 85.7 & 4 & 57.1 & 16 & 76.2 & \\
\hline
\end{tabular}

$\S \mathrm{p}$ value reached from Fisher exact test

Statistically significant sex difference was found between skeletal and dental patients' $\mathrm{p}>0.05$.

Table 4. Distribution of patients by type of malocclusion

\begin{tabular}{|c|c|c|c|c|c|c|}
\hline \multirow[t]{2}{*}{ Type of malocclusion } & \multicolumn{4}{|c|}{ Patient's group } & \multicolumn{2}{|c|}{$\begin{array}{l}\text { Total } \\
n=21\end{array}$} \\
\hline & No. & $\%$ & No. & $\%$ & No. & $\%$ \\
\hline Class I & 9 & 42.85 & 1 & 4.76 & 10 & 47.6 \\
\hline Class II & 3 & 14.28 & 6 & 28.56 & 9 & 42.9 \\
\hline Class III & 1 & 4.76 & 1 & 4.76 & 3 & 9.5 \\
\hline
\end{tabular}

Data shows that class I patients were found to be high in both group of patients $47.6 \%$ followed by class II $42.9 \%$ and class III $9.5 \%$.

Table 5. Distribution of the patients by causes of open bite

\begin{tabular}{lcc}
\hline Causes of open bite & Number & \% \\
\hline Tongue thrust & 11 & 52.3 \\
Hereditary & 3 & 14.4 \\
Short upper lip & 2 & 9.5 \\
Nasal obstruction & 1 & 4.8 \\
Thumb sucking & 4 & 19 \\
\hline
\end{tabular}

Causes of the open bite indicated that highest percentage had tongue thrust $52.3 \%$ 
Table 6. Distribution of the patients by treatment modality

\begin{tabular}{|c|c|c|c|c|c|c|}
\hline \multirow[t]{2}{*}{ Treatment modality } & \multicolumn{4}{|c|}{ Patient's group } & \multicolumn{2}{|c|}{$\begin{array}{l}\text { Total } \\
n=21\end{array}$} \\
\hline & No. & $\%$ & No. & $\%$ & No. & $\%$ \\
\hline Habit correction with tongue crib & 9 & 64.3 & 3 & 42.9 & 12 & 57.1 \\
\hline Non extraction & 8 & 57.1 & 0 & .0 & 8 & 38.1 \\
\hline Extraction 4 1st premolar & 3 & 21.4 & 5 & 71.4 & 8 & 38.1 \\
\hline Extraction 4 2nd premolar & 0 & .0 & 1 & 14.3 & 1 & 4.8 \\
\hline Extraction 2 upper 1st premolar & 1 & 7.1 & 0 & .0 & 1 & 4.8 \\
\hline Extraction 2 lower 1st premolar & 2 & 14.3 & 1 & 14.3 & 3 & 14.3 \\
\hline Romovable appliance & 6 & 42.9 & 0 & .0 & 6 & 28.6 \\
\hline Fixed appliance & 8 & 57.1 & 7 & 100.0 & 15 & 71.4 \\
\hline
\end{tabular}

*Multiple responses

It was revealed that highest percentage of the patients received fixed appliance $71.4 \%$ followed by habit correction with tongue crib $57.1 \%$. However, $38.1 \%$ of the patients were treated without extraction. Data revealed that the proportion of habit correction with tongue crib and removable appliance were required in dental group of patients whereas fixed appliance and extraction were needed more in skeletal group of patients.

Table 7. Pre and post treatment study model analysis of both group

\begin{tabular}{lcccccc}
\hline Study model analysis & Dental $\mathrm{n}=14$ & & \multicolumn{2}{c}{ Skeletal $\mathrm{n}=7$} \\
& Pre treatment & Post treatment & $\mathrm{p}$ value & Pre treatment & Post treatment \\
\hline Over jet & -.070 .3 & 2.40 .4 & $0.001^{*}$ & -0.90 .5 & 2.80 .6 \\
Over bite & -1.60 .9 & 2.30 .5 & $0.001^{*}$ & -2.61 .0 & 2.40 .4 \\
\hline
\end{tabular}

$\mathrm{p}$ value reached from paired $\mathrm{t}$ test

Data analysis revealed significant changes in overjet and over bite in both groups of patients $\mathrm{p}<0.05$.

Table 8. Pre and post treatment cephalometric analysis of the skeletal and dental groups

\begin{tabular}{|c|c|c|c|c|c|c|}
\hline \multirow[t]{2}{*}{ Cephalometric analysis } & \multicolumn{3}{|c|}{ Dental $n=14$} & \multicolumn{3}{|c|}{ Skeletal $\mathrm{n}=7$} \\
\hline & Pre treatment & Post treatment & $\mathrm{p}$ value & Pre treatment & Post treatment & $\mathrm{p}$ value \\
\hline Mandibular plane angle & $36.4+3.9$ & $35.7 \pm 3.8$ & $0.055^{*}$ & $42.0+5.7$ & $40.4+5.3$ & $0.025 *$ \\
\hline Gonial angle & $127.6 \pm 4.1$ & $127.3 \pm 4.0$ & 0.292 & $132.9 \pm 6.4$ & $132.9 \pm 6.4$ & - \\
\hline Palatal plane angle & $28.6 \pm 4.6$ & $28.1 \pm 4.2$ & 0.111 & $33.4 \pm 6.5$ & $32.1 \pm 6.4$ & $0.022 *$ \\
\hline Palatal plane & $7.9+2.4$ & $7.6+1.9$ & 0.513 & $8.6+3.8$ & $8.3+3.3$ & 0.356 \\
\hline Angle between SGn \& SN & $69.2 \pm 5.9$ & $68.8 \pm 5.1$ & 0.306 & $72.9 \pm 5.4$ & $71.7 \pm 5.1$ & $0.015^{*}$ \\
\hline Angle between SN plane to A point & $85.0 \pm 2.6$ & $81.4 \pm 1.4$ & $0.001 *$ & $82.1 \pm 2.3$ & $80.6+1.1$ & 0.052 \\
\hline Angle between SN plane to B point & $81.0 \pm 4.0$ & $78.8 \pm 1.5$ & $0.013^{*}$ & $77.0 \pm 3.6$ & $78.1 \pm 1.1$ & 0.339 \\
\hline Difference between SNA \& SNB & $4.0 \pm 3.8$ & $2.6 \pm 0.9$ & 0.119 & $4.9 \pm 3.7$ & $2.4 \pm 0.8$ & 0.096 \\
\hline
\end{tabular}

$\mathrm{p}$ value reached from paired $\mathrm{t}$ test

Cephalometric analysis of the patients indicated that among the dental group mandibular plane angle, angle between SN plane to A point and angle between SN plane to B point significantly decreased from pretreatment $\mathrm{p}<0.05$. In the skeletal group mandibular plane angle, palatal plane angle, angle between SGn \& SN, between SN plane to A point significantly decreased from pre-treatment status $\mathrm{p}<0.05$. However, no statistically significant difference was seen in cephalometric parameters of gonial angle and difference between SNA \& SNB p $>0.05$. 
Table 9. Pre and post treatment dental measurement of the skeletal and dental groups

\begin{tabular}{|c|c|c|c|c|c|c|}
\hline \multirow[t]{2}{*}{ Cephalometric analysis } & \multicolumn{3}{|c|}{ Dental $n=14$} & \multicolumn{3}{|c|}{ Skeletal $\mathrm{n}=7$} \\
\hline & Pre treatment & Post treatment & $\mathrm{p}$ value & Pre treatment & Post treatment & $\mathrm{p}$ value \\
\hline Upper incisor angulation & $115.3 \pm 5.0$ & $111.8+3.4$ & 0.036 & $115.1 \pm 9.9$ & $113.1 \pm 5.9$ & 0.472 \\
\hline Upper incisor protrusion & $8.1 \pm 1.8$ & $3.9 \pm 0.8$ & 0.001 & $9.0 \pm 3.5$ & $4.0 \pm 1.2$ & 0.003 \\
\hline Lower incisor angulation & $101.9 \pm 9.2$ & $93.6 \pm 3.7$ & 0.001 & $97.3 \pm 7.3$ & $94.0 \pm 1.2$ & 0.257 \\
\hline Lower incisor protrusion & $10.5 \pm 3.5$ & $4.6 \pm 1.3$ & 0.001 & $9.1 \pm 4.3$ & $4.4 \pm 1.4$ & 0.013 \\
\hline Inter-incisal angle & $108.5 \pm 11.9$ & $124.6 \pm 4.2$ & 0.001 & $113.0 \pm 10.3$ & $122.4 \pm 4.8$ & 0.024 \\
\hline Upper face height & $53.1 \pm 6.1$ & $54.1 \pm 5.5$ & 0.002 & $53.9 \pm 5.7$ & $54.9 \pm 5.5$ & 0.038 \\
\hline Lower face height & $71.9 \pm 7.9$ & $72.1 \pm 8.9$ & 0.739 & $73.9 \pm 5.5$ & $73.9 \pm 4.9$ & 1.00 \\
\hline Anterior face height & $125.1 \pm 12.0$ & $125.5 \pm 12.3$ & 0.416 & $127 . \overline{4} \pm 9.8$ & $128 . \overline{3} \pm 9.3$ & 0.017 \\
\hline Posterior face height & $78.7 \pm 11.1$ & $80.4 \pm 10.5$ & 0.001 & $77.3 \pm 7.5$ & $78.4 \pm 7.3$ & 0.047 \\
\hline
\end{tabular}

$\mathrm{p}$ value reached from paired $\mathrm{t}$ test

Data analysis revealed that in the dental group of patients upper incisor angulation, upper incisor protrusion, lower incisor angulation, lower incisor protrusion, and upper facial height decreased from pre-treatment status, whereas inter-incisal angle, upper facial height and posterior facial height increased from pre-treatment status $\mathrm{p}<0.05$. But no statistically significant mean difference was found in other variables $\mathrm{p}>0.05$. On the contrary, upper incisor protrusion and lower incisor protrusion was decreased from pre-treatment status $\mathrm{p}<0.05$ among the dental group of patients. It was also noted that inter-incisal angle, upper facial height, anterior facial height and posterior facial height increased from pre-treatment status $\mathrm{p}<0.05$.

Table 10. Pre and post treatment soft tissue analysis of the skeletal and dental groups

\begin{tabular}{lcccccc}
\hline Soft tissue analysis & & Dental $\mathrm{n}=14$ & & \multicolumn{2}{c}{ Skeletal $\mathrm{n}=7$} \\
& Pre treatment & Post treatment & $\mathrm{p}$ value & Pre treatment & Post treatment & $\mathrm{p}$ value \\
\hline Inter-labial gap & 1.53 .9 & 0.00 .0 & 0.178 & 7.46 .2 & 1.42 .5 & 0.027 \\
Esthetic plane & 4.63 .7 & 1.62 .6 & 0.001 & 4.64 .9 & 2.62 .4 \\
& & & & & \\
\hline
\end{tabular}

$\mathrm{p}$ value reached from paired t test

Data analysis shows that inter-labial gap significantly decreased in skeletal group of patients $\mathrm{p}<0.05$, but not in dental group $\mathrm{p}>0.05$. It was also found that the esthetic plane also significantly decreased after treatment in dental group of patients $\mathrm{p}<0.05$, but no statistically significant changes was observed in skeletal patients $(\mathrm{p}>0.05)$.

Table 11. Distribution of the patients by duration of treatment

\begin{tabular}{|c|c|c|c|c|c|c|c|}
\hline \multirow[t]{3}{*}{$\begin{array}{l}\text { Duration of treatment } \\
\text { (months) }\end{array}$} & \multicolumn{4}{|c|}{ Patient's group } & \multicolumn{2}{|c|}{$\begin{array}{l}\text { Total } \\
\mathrm{n}=21\end{array}$} & \multirow[t]{3}{*}{$\mathrm{p}$ value } \\
\hline & \multicolumn{2}{|c|}{$\begin{array}{c}\text { Dental } \\
\mathrm{n}=14\end{array}$} & \multicolumn{2}{|c|}{$\begin{array}{c}\text { Skeletal } \\
\mathrm{n}=7\end{array}$} & \multirow[b]{2}{*}{ No. } & \multirow[b]{2}{*}{$\%$} & \\
\hline & No. & $\%$ & No. & $\%$ & & & \\
\hline$<20$ & 8 & 57.1 & 1 & 14.3 & 9 & 42.9 & \\
\hline$\geq 20$ & 6 & 42.9 & 6 & 85.7 & 12 & 57.1 & \\
\hline Mean $\pm \mathrm{SD}$ & \multirow{2}{*}{\multicolumn{2}{|c|}{$\begin{array}{c}18.2 \pm 3.1 \\
12-24\end{array}$}} & \multirow{2}{*}{\multicolumn{2}{|c|}{$\begin{array}{c}24.0 \pm 4.1 \\
16-30\end{array}$}} & \multirow{2}{*}{\multicolumn{2}{|c|}{$\begin{array}{c}20.1+4.4 \\
12-30\end{array}$}} & \multirow[t]{2}{*}{$0.004 *$} \\
\hline Range & & & & & & & \\
\hline
\end{tabular}

*value reached from Mann-Whitney U test

The mean duration of treatment was $24.0 \pm 4.1$ months among the skeletal group and the mean duration was $18.2 \pm 3.1$ months among the dental group, but the mean difference was statistically significant $\mathrm{p}<0.05$. This indicated that skeletal group of patients needed more time than the dental group.

Bangladesh Journal of Orthodontics and Dentofacial Orthopedics (BJO \& DFO)

Vol. 2, No. 2, April 2012 
Table 12. Distribution of the patients by prognosis of treatment

\begin{tabular}{|c|c|c|c|c|c|c|c|}
\hline \multirow[t]{3}{*}{ Prognosis of treatment } & \multicolumn{4}{|c|}{ Patient's group } & \multirow{2}{*}{\multicolumn{2}{|c|}{$\begin{array}{l}\text { Total } \\
n=21\end{array}$}} & \multirow[t]{3}{*}{$\mathrm{p}$ value } \\
\hline & \multicolumn{2}{|c|}{$\begin{array}{c}\text { Dental } \\
n=14\end{array}$} & \multicolumn{2}{|c|}{$\begin{array}{c}\text { Skeletal } \\
n=7\end{array}$} & & & \\
\hline & No. & $\%$ & No. & $\%$ & No. & $\%$ & \\
\hline Corrected & 12 & 85.7 & 5 & 71.4 & 17 & 81.0 & 0.574 \\
\hline Partially corrected & 2 & 14.3 & 2 & 28.6 & 4 & 19.0 & \\
\hline
\end{tabular}

$\S p$ value reached from Fisher's exact test

Data analysis revealed the overall prognosis was favourable $81.0 \%$. Prognosis was found to be high among the dental group of patients $(85.7 \%)$ compared to skeletal group $(71.4 \%)$, which was not statistically significant $(p>0.05)$.

\section{DISCUSSION}

The present study was carried out to evaluate the pattern of malocclusion among the armed forces family members seeking orthodontic treatment. The incidence of open bite malocclusion was $2.3 \%$ in the study. The study commensurate with the study of other communities like Caucasians $(2.9 \%),{ }^{15}$ The present study also varies with other studies like $8 \%$ in Kenya, ${ }^{16} 6.6 \%$ in Saudi Arabia, ${ }^{17}$ 4\% in Pakistan, $198.7 \%$ in Colombia. ${ }^{18}$ This might be due to different nature and number of samples. The present study shows females had higher preponderance $(76.2 \%)$ over the male subjects $(23.8 \%)$. It might be due to more consciousness of the females towards aesthesis (Table 1,2,3) The present study was undertaken to determine the incidence in Angle's malocclusion criteria also, the majority (47.6) of open bite cases had Class I malocclusion. The finding are in close agreement with Hossain et al. ${ }^{20}$ (Table 4) While differentiating the etiology in this study, tongue thrust found to be the main cause $(71.4 \%)$, followed by heredity, nasal obstruction and short upper lip. Several studies are in favour of our study stating the compex etiology of open bite malocclusion. ${ }^{1-14}$ (Table 5 )

In this study, the treatment modalities of open bite were habit correction with tongue crib $(57.1 \%)$, Extraction (61.9\%), Removable appliance therapy $(28.6 \%)$, Fixed appliance therapy (71.4\%) and no surgery was undertaken. The study coincides with Kim Y, ${ }^{35}$ Lopez Gavito et al, ${ }^{33}$ Schudy. ${ }^{39}$ The treatment of open bite with removable appliances are advocated by many authors and treatment result is nearer to this study. ${ }^{30,31,37}$ However, some study advocates different concepts like functional appliances, ${ }^{42,44,45}$ molar intrusion, ${ }^{36}$ segmental distraction and surgery. ${ }^{12}$ The difference in treatment modalities are due to variations in age of individuals and a wider community scope for treatment (Table 6 ). In the study pre and post treatment model analysis showed significant changes in overbite and overjet in both group of patients. This is a positive prognostic indicator of successful treatment (Table 7). Cephalometric analysis of the patients in vertical measurements indicated that mandibular plane angle, palatal plane angle and SNA angle significantly decreased in post treatment $\mathrm{p}<0.05$ (Table 9). It is interesting to note that the values are nearer to Cangialossi, and Gershater values, ${ }^{9,24}$ that the post treatment reduction in these angles results in greater lower anterior face height caused by a downward tipping of the mandibular plane. These parameters were insignificant between the two groups-dental open bite and skele- tal open bite subjects (Table 8). Cephalometric datas on dental and linear measurements revealed that upper incisor protrusion, lower incisor angulation and lower incisor protrusion significantly decreased after treatment. At the same time Inter incisal angle, upper face height and posterior facial height significantly increased after treatment. These changes are indicators of success of treatment. In open bite subjects the upper facial height and the posterior facial height is less causing a long facial with greater lower facial height. Reduction in the posterior facial height and an steep mandibular plane angle rather worsen the condition since it brings rotational changes in mandible (Table 9). These are consistent with studies carried out by Remmers et al, ${ }^{41}$ Sassouni and Chang. ${ }^{25,26}$

Soft tissue analysis showed significant decrease in interlabial gap and esthetic plane in both groups ( Table 10 ). Generally the skeletal open bite cases had large interlabial gap. A reduction in it has a positive influence on patients esthetic plane and facial profile. Data analysis regarding the duration of treatment, the skeletal group required more treatment time (24.0.土4.1 months) than the dental group (18.2 \pm 3.1 months). The mean duration was significant ( Table 11). Statistically significant results were found regarding the prognosis and patient satisfaction of treatment (Table 12). Favorable prognostic outcome was found among the dental group $(85.7 \%)$ compared to skeletal group (71.4\%) (Table 12).

\section{CONCLUSION}

From the result of the present investigation and its conclusion, it may be suggested that incidence of open bite was $2.3 \%$. The treatment period and wear time of appliance in dental type of open bite was shorter than those of skeletal type of open bite. All subjects showed significant improvement - both skeletal and dental group, though prognosis was better in dental type of open bite cases.

\section{REFERENCES}

1. Uribe F, Nanda R. Management of open bite malocclusion, Biomechanics and esthetic strategies in clinical orthodontics. St. Louis. Missouri: Elsevier Saunders 2005: p. 156-86.

2. Peter Ngan, Henry W. Fields .Open bite: a review of etiology and management. American Academy of Pediatric Dentistry 1997;19(2):91-8.

3. John E. Bilodeau .Vertical considerations in diagnosis and treatment. A surgical orthodontic case report. Am J Orthod Dentifac 
Orthop 1995;107:91-100

4. Proffit W, Fields H. 2008. Contemporary Orthodontics. Mosby year book, fourth edition.

5. Cristina Tostes Vieira Maciel; Isabel Cristina Gonclaves Leite.: Etiological aspect of anterior open bite and its implications to ora functions.Pro-Fono Revista de Atualizacao Cientifica; 2005vol 17, no 3 page1- 19.

6. Kuitert R, Beckmann S, Loenen M V, Tuinzing B, Zenter A. Dentoalveolar compensation in subjects with vertical skeletal dysplasia. American Journal of Orthodontics and Dentofacial Orthopedics 2006;129:649-657.

7. F. F. Schudy .The rotation of the mandible resulting from growth: Its implication in orthodontic treatment. The Angle Orthodontist 1965; 35(1):36-50.

8. Leth Nielsen .Vertical malocclusions: etiology, development, diagnosis and some aspects of treatment. Angle Orthodontist 1991 ; 61(4):247-60.

9. M. M. Gershater .The proper perspective of open bite. Angle Orthodontist 1972: 42(3):263-72.

10. C. Wayne Neff, William L. Kydd .The open bite: Physiology and occlusion. Angle Orthodontist 1966; 36(4):351-57.

11. S. Miyawaki, Y. Araki, Y. Tanimoto, A. Katayama, A. Fujii, M. Imai and T. Takano-Yamamoto .Occlusal force and condylar motion in patients with anterior open bite. J. Dent Res 2005; 84(2):133-37.

12. Schendel S A, Eisenfeld J, Bell W H, Epker B N, Mishelevich D J The long face syndrome: vertical maxillary excess. American Journal of Orthodontics 1976;70:398-408.

13. Otuyemi O.D., Noar J.H. Anterior open-bite: A review. The Saudi Dental Journal 1997; 9(3):149-57.

14. Zuleyha Mirzen Arat, Mehmet Okan Akcam, Elcin Esenlik, F. Emel Arat .Inconsisstencies in the differential diagnosis of Open bite. Angle Orthodontist 2008; 78(3):415-420.

15. Ackerman and Proffit The characteristics of malocclusion: A modern approach to classification and diagnosis. Am J Orthod 1969: 443-454.

16. Ng'ang'a P M. Ohito F. Ogard B . Valderhaug J The prevalence of malocclusion in 13-to 15-year-old children in Nairobi, Kenya. Acta Odontologica Scandinavica 1996;54: 126-130

17. Al-Emran S, Wisth PJ, Boe OE . Prevalence of malocclusion and need for orthodontic treatment in Saudi Arabia. Community Dent. Oral epidemiol 1990;18:253-5.

18. Thailander B, Pena L, Infante C, Panda S S et al. Prevalence of malocclusion and treatment need in children and adolescents in Bogota, Columbia. An epidemiological study related to different stages of dental development. 2001; $23: 153-167$.

19. Marwat H. J, Amin B, Khan A. Frequency of Anterior Open bite patients repirting to AFID, Rawalpindi, Pakistan oral and dental journal 2009; 28(1): 71-74

20. Hossain M Z, Haque S, Yasmin S, Haque A et al, Prevalence of Malocclusion and Treatment facilities at Dhaka Dental College and Hospital, J of Oral Health 1994; 1 : 4-6.

21. Akhter F. . Evaluation of different malocclusion and probable treatment based on IOTN(Index of Orthodontic Treatment Need) attending at Dhaka Dental College and Hospital. Thesis, BCPS, Dhaka, 2006 page 43.

22. Bjork. Prediction of mandibular growth rotation. American J Orthod 1969; 39-53.

23. Yu-Ching Wang, Ellen Wen-Ching Ko .The nature of open bite. J. Taiwan Assoc. Orthod. 2005;17(2):35-41.

24. Cangialosi T. Skeletal morphologic features of anterior open bite. Am J Orthod 1984;85:28-36.

25. Sassouni V, Nanda SK, . Analysis of dentofacial vertical proportions. Am J Orthod 1964;50:801-823.

26. Chang Y,. Cephalometric evaluation of anterior open bite treatment. Am J Orthod 1999;115:29-38.
27. Raymond E. A cephalometric evaluation of anterior open-bite correction with the magnetic active vertical corrector. Am J Orthod 1991: 2:93-102.

28. Worms F., Meskin L., Isaacson R. Open bite. Am J Orthod 1971: 59:589-95.

29. Nanda S K Patterns of vertical growth in the face. American Journal of Orthodontics and Dentofacial Orthopedics 1988: 93:103-116.

30. Paola Cozza; Manuela Mucedero; Tiziano Baccetti; Lorenzo Franchi. Early Orthodontic Treatment of Skeletal Open-bite Malocclusion :A Systematic Review .Angle Orthod 2005;75:707713.

31. Chui Shan Teresa NG, Wing Kit Ricky Wong, Urban Hagg. Orthodontic treatment of anterior open bite. International Journal of Paediatric Dentistry 2008;18:78-83.

32. Subtelny JD, Subtelny JD. Oral habits- studies in form, function, and therapy. Angle Orthod 1973;43:347-383.

33. Lopez-Gavito G, Wallen T R, Little R M, Joondeph D R. 1985: Anterior open bite malocclusion, a longitudinal 10 year post-retention evaluation of orthodontically treated patients. American Journal of Orthodontics 87:175-186

34. Sankey W L, Buschang P H, English J, Owen A H. Early treatment of vertical skeletal dysplasia: the hyperdivergent phenotype. American Journal of Orthodontics and Dentofacial Orthopedics 2000;118:317-327.

35. Kim Y. Anterior open bite and its treatment with multoloop edgewise archwire. Angle Orthod 1987; 57:290-321

36. Ervevdi N, Usumez S, Solaka A, Koldas T. Non compliance open bite treatment with zygomatic anchorage. Angle Orthod 2007;77:986-990

37. Perdin F, Almeida MR, Almeida RR, Almeida-Perdin RR, Torres F. A prospective study of the treatment effects of a removable appliance with palatal crib combined with high-pull chin cup therapy in anterior open bite patients. Am J Orthod and Dentofacial Orthop. 2006;129(3):418-23.

38. Huang G J. Long term stability of anterior open bite therapy: a review. Seminars in Orthodontics 2002;8:162-172.

39. Katsaros C, Berg R. Anterior open bite malocclusion, a follow up study of orthodontic treatment effects. European Journal of Orthodontics 1993;15:273-280.

40. Schudy F F: The control of vertical overbite in clinical orthodontics. Angle Orthodontist 1968;38:19-39.

41. D Remmers, RWGJ Van`t Hullenaar, EM Bronkhorst, SJ Berge, C Katsaros .Treatment results and long term stability of anterior open bite malocclusion. Orthod Craniofac Res 2008; 11:32-42.

42. Camelia A. Fleser, Cristina D. Bratu, Florica Glavan .Functional orthodontic therapy in skeletal open bite. TMJ 2004; 54(2):198-200.

43. Peter A Shapiro .Stability of open bite treatment. American Journal of Orthodontics and Dentofacial Orthopedics 2002: 121:566-8.

44. Paola Cozza, Tiziano Baccetti, Lorenzo Franchi and Manuela Mucedero .Comparison of 2 early treatment protocols for open bite malocclusions. American Journal of Orthodontics and Dentofacial Orthopedics 2007; 132:743-7.

45. Tiziano Baccetti, Lorenzo Franchi, Scott O. Schulz and James A. Mcnamara Treatment timing for an orthopedic approach to patints with increased vertical dimension. . Am J Orthod Dentifac Orthop $2008 ; 133: 58-64$

\section{Correspondence :}

\section{Dr. Md. Anisur Rahman BDS, FCPS}

Lieutenant Colinel,

Combined Military Hospital,

Rangpur Cantonment.

Mobile : +8801711380 282, E-mail : anis30@gmail.com 